UNRAM Law Review is licensed under a Creative Commons Attribution 4.0 International License, which permits unrestricted use, distribution, and reproduction in any medium, provided the original work is properly cited. p-ISSN: 2548-9267 | e-ISSN : 2549-2365, Open Access at : http://unramlawreview.unram.ac.id/index.php/ulr

\begin{tabular}{c|c|c|c|c|}
\hline Volume & Issue & Page & April & p-ISSN: 2548-9267 \\
\hline 4 & 1 & $1-10$ & 2020 & e-ISSN : 2549-2365
\end{tabular}

\title{
Criminal Liability in Environmental Crimes Committed by Corporations after the Supreme Court Regulation Number 13 of 2016 at Indonesia
}

\author{
Fitriani Rahmadia \\ Faculty of Law, Diponegoro University \\ Jl. Imam Bardjo, S.H., No. 1-3, Kampus Pleburan, Semarang \\ Email: rahma.diya@gmail.com \\ Hari Sutra Disemadi \\ Faculty of Law, Diponegoro University \\ Jl. Imam Bardjo, S.H., No. 1-3, Kampus Pleburan, Semarang \\ Email: haridisemadi@gmail.com \\ Nyoman Serikat Putra Jaya \\ Faculty of Law, Diponegoro University \\ Jl. Imam Bardjo, S.H., No. 1-3, Kampus Pleburan, Semarang \\ Email: putrajaya1984@yahoo.co.id
}

\begin{abstract}
Corporations are organized groups of people and/or properties, both in the form oflegal entities or non-legal entities. In relation to the corporation as a legal subject in environmental crime, it is formulated in Article 1 number 32 of the Law Number 31 Year 2009 about Environmental Protection and Management, each person is an individual or business entity, both legal entities and non-legal entities. The context of corporate crime in the environment is still not solid enough to ensure corporations in criminal sanctions because there is no legal basis regarding the procedures for handling environmental crimes committed by corporations. The Supreme Court Regulation Number 13 of 2016 concerning Procedures for Handling Corporate Crime provides a basis for enforcement of criminal law, then the purpose of writing this article is to find out the form of criminal liability for corporations for environmental crimes and legal consequences after the Supreme Court Regulation Number 13 of 2013.The type of research used is legal research which is included in the normative legal research typology where this study focuses on positive legal norms in the form of legislation. The theory used by the author in analyzing is using the theory of criminal liability which is based on the principle of legality. The conclusions include: criminal sanctions that can be applied to corporations based on Article 4 of Supreme Court Regulation Number 13 of 2016 are in the form of criminal fines, additional crimes, and disciplinary actions except prisons and confinement. Last, the legal consequences of the application Article 25 Supreme Court Regulation Number 13 of 2016 with the principal criminal is a criminal fine and then the criminal added according to the law governing environmental criminal acts is the Law Number 32 Year 2009 concerning Environmental Protection and Management.
\end{abstract}

Keywords: Corporate Responsibility; Environmental Crime. 


\section{INTRODUCTION}

Corporations in Dutch: corporatie, English: corporation, German: corporation, all come from the word "corporation" in Latin, substantially (substantivum) from the word "corporare" used by people in the middle ages or afterwards, while corporare itself comes from the word "corpus" in Indonesian means body or giving body or body, means corporatio the result of body work. ${ }^{1}$ The term of corporation is very closely related to the term "legal entity" which is known in the field of civil law. ${ }^{2}$

The issue of corporation as a subject of criminal law cannot be separated from aspects of civil law. In private law, individuals are not the only legal subjects. This is due to the fact that there are still other legal subjects who have rights and can carry out legal actions the same as individuals. This view is different from the Criminal Code which only acknowledge individuals as legal subjects. There are three applicable sanctions which can be in the form of: criminal fines, additional crimes, and disciplinary action. But there are criminal sanctions applied to criminal subjects in the form of people who cannot be applied to corporations, such as prisons or confinement. Additional criminal charges or disciplinary action can take the form of: 1). deprivation of profits derived from criminal acts; 2 ). the closure of all or part of the place of business and / or activity; 3 ). improvement due to criminal acts; 4 ). the obligation to do what is done without rights; and / or 5). placement of the company under the maximum period of 3 (three) years.

Basically there are four theories regarding corporate criminal liability. First, identification theory (identification theory) is commonly referred to as direct corporate criminal liability or direct corporate criminal liability. According to this theory, corporations can carry out a number of offenses directly through the management that is very closely related to the corporation, acting for and on behalf of the corporation so that it is seen as the company itself. Second, strict liability which Smith \& Hogan defines strict liability as crimes which do not require intention, recklessness or even negligent or more elements in the actusreus. Therefore, strict liability is defined as strict liability according to the law regardless of who made the mistake. Third, vicarious liability. Basically this teaching is closely related to the doctrine of respondent superior, namely the relationship between the master and servant or between the principal and agent. The relationship is then strengthened by the adagio which reads qui facitper aliumfacit per se which means that someone who acts through another person is considered to be himself who did the act. ${ }^{3}$ Last, fuctioneel daderschap (theory of functional actors) which is developing from a Continental European country, was first stated by Roling in his notes under the ruling of Hoge Raad on 31 January and 21 February 1950. He saw a tendency in criminal law to increasingly detach from the human context.

Emergency Law Number 7 of 1955 concerning the Investigation, Prosecution and Judgment of Economic Crimes states firmly that the subjects of criminal law are persons and legal entities of companies, unions, and foundations; All types of business forms refer to "corporation". This is different from the Criminal Code which states that the subjects of criminal law are individuals. In reality, white collar crimes often occur in the form of corporate crime, banking crime and corruption. Corporate crime is not chosen by an evil impulse, but by something

1 Yudi Krismen. (2014). "Pertanggungjawaban Pidana Korporasi dalam Kejahatan Ekonomi”, Jurnal Ilmu Hukum Riau, 5(1): 133-160, < DOI: http://dx.doi.org/10.30652/jih.v4i1.2089>, p. 140.

2 Kristian. (2014), "Urgensi Pertanggungjawaban Pidana Korporasi", Jurnal Hukum Dan Pembangunan, 44(4): 575-621, < DOI: http://dx.doi.org/10.21143/jhp.vol44.no4.36>, p. 550.

3 Hariman Satria. (2017). "Penerapan Pidana Tambahan Dalam Pertanggungjawaban Pidana Korporasi Pada Tindak Pidana Lingkungan Hidup", Jurnal Yudisial, 10(2): 155-171, <DOI: http://dx.doi.org/10.29123/jy.v10i2.18>, p. 160. 
that is not felt morally. ${ }^{4}$ These crimes seriously hurt people's feelings about justice, honesty, solidarity, and social responsibility. In terms of a corporation is a combination of people who in legal association act together as separate legal subjects. Corporations are legal entities whose members have their own rights and obligations separate from the rights and obligations of each member. ${ }^{5}$

Discussion about the corporation is actually familiar to us; even lately we often hear about corporate strategy whether it is mergers, acquisitions, consolidation, tax planning and others. Corporations contribute significantly to the development of a country, especially in the economic field, for example state revenues in the form of taxes and foreign exchange, so that the impact of the corporation looks very positive. On the other hand, corporations also often create negative impacts, such as pollution, depletion of natural resources, fraudulent competition, tax manipulation, exploitation of labor, produce products that endanger the user, and fraud against consumers. Corporations can increase state wealth and labor, but revolutionize the economic structure and politics has grown a great corporate power, so that the state is too dependent on corporations so that the state can be dictated according to its interests. Giant companies not only own such great wealth, but also own social and political strength in such a way that the operations or activities of these companies greatly affect the lives of everyone from birth to death. The work life and health and safety of the majority of the population are controlled either directly or indirectly by these large companies. ${ }^{6}$ It has been proven that multinational companies have exercised political influence both on the government at home and abroad where the company operates.

The relation of the role corporations as legal subjects is also formulated in the provisions of Article 1 number 32 of Law Number 32 of 2009 concerning Environmental Protection and Management, stating that every person is an individual or business entity, both legal entity and non-legal entity. With the terminology used in Act Number 32 of 2009 concerning Environmental Protection and Management which refers to corporations using the term "business entity", corporations are part of the subject of environmental crimes and can be liable for criminal liability based on the provisions stipulated in Law Number 32 of 2009 concerning Environmental Protection and Management. However, it is important to note that the Supreme Court has issued Supreme Court Regulation Number 13 of 2016 concerning Procedures for Handling Criminal Cases by Corporations. So this will be the background for how corporate criminal liability for environmental crimes will be carried out.

Based on the background that has been described, several problems are obtained, including: 1). What about criminal liability for environmental criminal acts committed by the Corporation?; and 2). After Supreme Court Regulation Number 13 of 2016 concerning Procedures for Handling Criminal Cases by Corporations is enacted, then how is criminal liability of Corporate legal subjects for environmental crimes?.

\section{METHOD}

The type of research used is normative legal research, which focuses on positive legal norms in the form of legislation. Analytical descriptive is the nature of the research specifications

4 Oksimana Darmawan. (2018). "Pertanggungjawaban Pidana Korporasi Dalam Illegal Fishing Di Indonesia" Jurnal Yudisial, 11(2): 171-192, < DOI: http://dx.doi.org/10.29123/jy.v11i2.292>, p. 181.

5 Muh Abdul Qudus and Pujiyono. (2019). "Pertanggungjawaban Korporasi Terhadap Tindak Pidana Human Trafficking Di Indonesia", Jurnal Komunikasi Hukum (JKH), 5(2): 26-39, <DOI: http://dx.doi.org/10.23887/jkh.v5i2.18237>, p. 29.

6 Hari Sutra Disemadi and Nyoman Serikat Putra Jaya. (2019). "Perkembangan Pengaturan Korporasi Sebagai Subjek Hukum Pidana Di Indonesia", Jurnal Hukum Media Bhakti, 3(2): 118-127, <DOI: https://doi.org/10.32501/jhmb. v3i2.80>, p. 123. 
used by the author because the specifications of this study describe the problem of the object that is studied. ${ }^{7}$ The approach used by the author in this study is a conceptual approach. This approach stand from the views and doctrines that develop in the science of law. It is important because understanding the views/doctrines that develop in the science of law can be a foothold to build legal arguments when resolving legal issues at hand. Views/doctrines will clarify ideas by providing legal understandings, legal concepts, and legal principles that are relevant to the problem, which in this study is used Supreme Court Regulation Number 13 Year 2016. So the authors analyze by providing an understanding of related issues about Supreme Court Regulation Number 13 Year 2016.

This research used Secondary data. The technique used in collecting secondary data is through library research or documentary study, which is a study that examines various documents both related to legislation and other available documents. The data that has obtained then collected and arranged to be analyzed and explained to draw the conclusions of the research conducted.

\section{ANALYSIS AND DISCUSSION}

\section{Corporate Criminal Liability for Environmental Criminal Actions in Indonesia}

Corporate crime which is usually in the form of white-collar crime, is generally committed by a company or legal entity engaged in the business field with a variety of actions that are contrary to applicable criminal law. Based on experience from various developed countries, it can be stated that identification of corporate crimes can include criminal acts such as violations of monopoly laws, computer fraud, payment of taxes and excise, violations of price provisions, production of goods that endanger health, corruption, bribery, administrative violations, labor, and environmental pollution. In Indonesia, the regulation of Corporations as legal subjects has been regulated in Article 1 number 13 and Article 70 of Law Number 5 of 1997 concerning Psycho tropics, Article 1 paragraph (21), Article 75 letter b and Article 130 of Law Number 35 of 2009 concerning Narcotics, Article 1 number 1 and Article 20 of Law Number 31 of 1999 concerning Eradication of Corruption, Article 78 paragraph (14) of Law Number 41 of 1999 concerning Forestry, Articles 116, 117, 119 of Law Number 32 of Year 2009 concerning Environmental Protection and Management, Article 6 of Law Number 8 of 2010 concerning Prevention and Eradication of Money Laundering Crimes.

Victims of corporate crime are wider in scope than victims of crime in general (conventional crime) both in terms of the number of victims and losses incurred, so victims of corporate crime need special attention in preventing and overcoming corporate crime in this case in the form of accountability for corporate criminal acts against victims of corporate crime. ${ }^{8}$ It is important to ensure corporations for crimes committed through the laws and regulations governing corporate responsibility, but equally important is to provide protection and justice to victims of corporate crime.

Criminal liability was stated by Simon who formulated straafbaarfeit as "Eenestrafbaargestelde, onrechmatige, met schuld in verhandstaandehandeling van eentorekeningvatbaar person" (an act which by law, threatened with punishment, contrary to punishment, contrary to law, carried out by someone the guilty person and that person is

7 Hari Sutra Disemadi and Kholis Roisah. (2019). "Urgency of the Contempt of Court Criminalization Policy to Over come Harassment Against the Status and Dignity of Courts" Brawijaya Law Journal, 6(2): 224-233, < DOI: http:// dx.doi.org/>, p. 226.

8 Idi Amin. (2018). "Pertanggungjawaban Korporasi Dalam Tindak Pidana Lingkungan Hidup", Jurnal Ius Kajian Hu kum dan Keadilan, 6(2): 259-263, < DOI: http://dx.doi.org/10.29303/ius.v6i2.558>, p. 260. 
considered responsible for his actions). ${ }^{9}$ Regarding who can be held accountable for crimes committed by corporations is very important, because this is very closely related to criminal liability for crimes committed by corporations. If it has been identified who is responsible for crimes committed by corporations, then prosecution and criminal prosecution can be carried out to those who can be accounted for. ${ }^{10}$ In the Economic Criminal Act particularly in Article 15 paragraph (1) it has been determined that if a corporation commits a criminal offense, then the corporation that can be prosecuted and sentenced to criminal conduct is the corporation itself, which gives the order to commit a criminal offense, or both- both (the corporation and the one giving the orders). Law Number 23 of 1997 concerning Environmental Management in Article 46 paragraph (1) and (2) broadly determines that those liable for criminal liability are: (1) corporation or legal entity, corporation, association, foundation or other organization the said; (2) those who give orders to commit a crime; (3) or both, namely the corporation and those who give orders to commit a crime. ${ }^{11}$

In Indonesia, the development of corporations as subject to criminal offenses takes place outside the Criminal Code, in specific laws. While the Criminal Code itself still adheres to the subject of criminal acts in the form of people. There are similarities between the last two opinions which suggest that the notion of a corporation as a legal subject in criminal law is broader than the notion of a corporation as a legal subject in civil law. This is based on the arrangement of corporations as subject to criminal acts in special statutory regulations outside the Criminal Code. Corporate arrangements as subject to criminal offenses are contained in special legislation outside the Criminal Code, including:

a. Law Number 7 of Emergency 1955 concerning Economic Crimes. In Article 15 paragraph (1) it is stated that: "If an economic criminal offense is committed in the name of a legal entity, a corporation, an association, a person or a foundation, then .....";

b. Law Number 5 of 1984 concerning Industry. The mention of the corporation is not in writing, but in Article 21 paragraph (1) Juncto. Article 1 number 7 is called the subject of a criminal offense in the form of an "Industrial Company". Article 1 number 7 explains: "Industrial companies are business entities that carry out activities in the industrial business sector";

c. Law Number 6 of 1984 concerning Postal. In Article 19 paragraph (3) it is stated: “..... carried out by, or on behalf of, a corporate legal entity, an association of another person or foundation, .....";

d. Law Number 9 of 1985 Concerning Fisheries as amended by Act Number 31 of 2004. Where according to Article 6 paragraph (1), Article 7 paragraph (1) Jucto. Article 24, Article 10 paragraph (1) Jucto. Article 25, "Every person or legal entity is prohibited from carrying out .....";

e. Act Number 7 of 1992 concerning Banking as amended by Act Number 10 of 1998 . According to Article 46 paragraph (2) that, "......is carried out by a legal entity in the form of a limited liability company, union, foundation or corporation";

f. Law Number 8 of 1995 concerning Capital Markets. The subject mentioned in the offense formulation is "every party". What is meant by each party according to Article 1 number 23 is: "Individuals, companies, joint ventures, associations or organized groups";

g. Law Number 5 of 1997 concerning Psychotropics. In the formulation of psychotropic

9 Muladi and Dwidja Priyanto. (2012). Pertanggungjawaban Pidana Koorporasi. Semarang: Badan Penerbit Undip, p. 63.

10 Rusdianto Pratama. (2015). "Tindak Pidana Pencemaran Lingkungan Serta Pertanggungjawabannya Ditinjau Dari Hu kum Pidana Di Indonesia", Lex Crimen, 4(2): 105-116, p. 110.

11 Muladi and Dwidja Priyanto. Op.Cit., p. 63. 
crime, it is only referred to as "corporation". While the notion of corporation is explained in Article 1 number 13, which is "an organized collection of people and / or wealth, whether a legal entity or not". This law is the first to use the term corporation;

h. Law Number 22 Year 1997 concerning Narcotics. Also called corporation as in the psychotropic law. The definition of corporation is formulated in Article 1 number 19, which is "an organized collection of people and / or wealth, whether a legal entity or not";

i. Law Number 23 of 1997 concerning Environmental Management. According to Article 46 paragraph (1), it is determined ".....if done by or on behalf of a legal entity, corporation, association, foundation or other organization";

j. Law Number 5 of 1999 concerning Prohibition of Monopolistic Practices and Unfair Business Competition. The formulation of offenses in this law is only regulated in Article 48, which consists of violations of several articles in this law. In the articles mentioned in Article 48, there is no mention of a corporation or legal entity. The subject mentioned is "business actor". In the general provisions of Article 1 sub 5 it is explained that: "a business actor is any individual or business entity, whether in the form of a legal entity or not";

k. Law Number 8 of 1999 concerning Consumer Protection. The subject of a crime referred to in the offense formulation is a business actor in Article 62. The definition of a business actor is explained in Article 1 number 3, namely: "a business actor is every individual or business entity, whether incorporated or not", the same as the formulation in Law Number 5 of 1999;

1. Law Number 31 of 1999 concerning Eradication of Corruption Crimes as amended by Law Number 20 of 2001. Its formulation: “......if carried out by a corporation. The meaning is explained in Article 1 number 1, which is: "Corporations are organized organizations of people and / or wealth, whether they are legal entities or not legal entities";

m. Law Number 21 of 2001 concerning Oil and Gas. The term used is a business entity. The definition of a business entity is regulated in Article 1 number 17 which states: "a business entity is a company in the form of a legal entity that carries out a type of business that is permanent, continuous and established in accordance with applicable laws and regulations and works and is domiciled within the territory of the Unitary State of the Republic of Indonesia"; and

n. Law Number 8 of 2010 concerning Prevention and Eradication of Money Laundering Crimes. The term used is corporation. The meaning is explained in Article 1 number 10, namely: "an organized collection of people and / or wealth, whether a legal entity or not a legal entity".

From the various regulations above that formulate corporations as subject to criminal acts in legislation, it can be seen that the regulation of corporations as subjects of crime is contained in special laws outside the Criminal Code. In addition, these laws and regulations indicate that the notion of a corporation in the field of criminal law is broader than the notion of a corporation in the field of civil law. ${ }^{12}$

With regard to the types of sanctions that can be imposed on the corporation for the crimes committed, the sanctions are in the form of criminal fines, additional crimes, and disciplinary action. These three sanctions are types of sanctions that can be threatened to corporations in relation to the nature of the corporation as a subject of a crime that is different from the subject of a criminal act in the form of a human being or an individual person. Because there are

12 Muladi and Dwidja Priyanto. Loc.Cit. 
criminal sanctions applied to criminal subjects in the form of people who cannot be applied to corporations, such as prisons or confinement.

However, the prosecution will be constrained by the issue of indictment which is an important aspect in the prosecution of corporations as perpetrators of environmental crimes. While in Law Number 8 of 1981 concerning Criminal Procedure Law (the Criminal Procedure Code/ KUHAP), it does not determine the corporation as a subject of criminal law, this becomes a problematic later in the enforcement of environmental corporate criminal acts, for example the problem of the formality of the letter indictment. ${ }^{13}$

\section{Corporate Criminal Responsibilities for the Environmental Crime Following the Supreme Court Regulation Number 13 of 2016}

In 2016, the Supreme Court of the Republic of Indonesia issued regulations relating to the Procedure for the Mechanism of Handling Corporate Crimes. In the form of Supreme Court Regulation Number 13 of 2016 concerning Procedures for Handling Corporate Crimes. This Supreme Court Regulation aimed to address all problems along becomes obstacles in the handling of corporations as perpetrators of crime. Corporations in committing criminal acts can also be held accountable for corporate groups that were originally only imposed on corporate administrators who committed criminal acts. Article 6 of the Supreme Court Regulation Number 13 of 2016, "In the event that a criminal offense is committed by a corporation involving the parent corporation and / or subsidiary corporation and / or corporation that has a relationship can be criminally liable in accordance with their respective roles". According to the court, for example a corporation can be held liable if: a). the corporation knows that there is a discharge carried out by its subordinates; $b$ ). the corporation has the power / authority to prevent criminal acts (ie waste disposal); and c). the corporation failed to prevent the crime. ${ }^{14}$

With regard to corporations as perpetrators of environmental crimes, taking into account the formulation of environmental crimes, in Article 1 number 32 of Law Number 32 Year 2009 concerning Environmental Protection and Management, what is meant by every person is an individual or business entity, whether incorporated, or not incorporated, in other words the legal subject can also be a corporation.

As previously explained in the background, there are several theories regarding criminal liability, including: identification theory, vicarious liability theory, strict liability theory, and functioneel dadeershap theory. Sutan Remy Sjahdeni tries to interpret the contents of Article 20 paragraph (2) of Law Number 32 of 2009 concerning Environmental Protection and Management and concludes that the article adopts identification theory. The presence of identification theory is indicated in the phrase "if the crime was committed by people both based on work relations or based on other relationships." 15 The phrase "people both based on work relationships and based on other relationships" consists of two groups of people. The first group are people based on work relationships, and the second are people based on other relationships. The relationship in question is interpreted as a relationship with the corporation concerned. ${ }^{16}$

Based on Article 4 paragraph (2) of the Supreme Court Regulation Number 13 of 2016, corporate error is can be seen from: 1). Corporations can benefit or benefit from the crime or the crime is committed for the benefit of the corporation; 2). Corporations allow criminal acts

13 Abdul Roup, Muridah Isnawati and Sudarto. (2017). "Pertanggungjawaban Pidana Korporasi Lingkungan Hidup Pasca Peraturan Mahkamah Agung No. 13 Tahun 2016", Justitia Jurnal Hukum, 1(2): 294-322, < DOI: http://dx.doi. org/10.30651/justitia.v1i2.1163>, p.296.

14 Amiad Kushner. (2003). "Applying The Responsible Corporate Officer Doctrine Outside The Public Welfare Con text", Journal of Criminal Law \& Criminology, 93(2): 681-712, p. 705-706.

15 Sutan Remy Sjahdeini, Pertanggungjawaban Pidana Korporasi (Jakarta: Gfitipers).

16 Ibid. 
to occur; or 3). The corporation does not take the necessary steps to prevent, prevent greater impact and ensure compliance with applicable legal provisions to avoid criminal offenses. ${ }^{17}$

As a result of environmental corporate criminal acts after being passed by the Supreme Court Regulation Number 13 of 2016 namely all the provisions of liability, sanctions and so on related to environmental corporate criminal acts in Act Number 32 of 2009 concerning Environmental Protection and Management becomes the legal basis in implementing all the provisions in Law Number 32 of 2009 concerning Environmental Protection and Management after the enactment of the Supreme Court Regulation Number 13 of 2016. In the decision and enforcement of the court award, the judge must stand and based on the provisions contained in Law Number 32 of 2009 concerning Environmental Protection and Management in making decisions on environmental corporate criminal acts. The form of accountability that can be found in the formulation of Supreme Court Regulation Number 13 of 2016 article 1 no 8 that a criminal offense by a corporation is a criminal offense that can be held liable to the corporation in accordance with the law governing the corporation. Article 3 Supreme Court Regulation Number 13 of 2016that a criminal offense by a corporation is a criminal offense committed by a person based on a work relationship, or based on other relationships, both individually and jointly acting for and on behalf of the Corporation inside and outside the corporate environment.

The formulation of liability is affirmed in Supreme Court Regulation Number 13 of 2016 article 4 paragraph (1) that corporations can be held liable for criminal liability in accordance with the provisions of corporate crime in laws governing corporations; (4) In imposing a criminal offense against a corporation, the Judge may assess corporate wrongdoings as referred to in paragraph (1), including: Corporations can benefit or benefit from the crime or the crime is committed in the interests of the corporation, the corporation allows the occurrence of criminal acts or the corporation does not commit the steps needed to take precautions, prevent greater impacts and ensure compliance with applicable legal provisions in order to avoid occurrence in order to avoid criminal offenses.

In enforcing environmental law, all forms of violations and crimes have been regulated, for perpetrators both committed by individuals and agencies with preventive and repressive measures. For repressive measures, there are several types of instruments that can be applied and their application depends on their needs, as a consideration, among others, see the impact caused. ${ }^{18}$

The types of instruments referred to include: 1). Administrative Actions; 2). Civil Actions (Civil Process); and 3). Criminal Acts (Criminal Process). Of the three forms of the instrument there is no priority scale or is the first and last order, so that if there is an assumption of criminal action is the last punishment in its application and if other actions do not resolve it. ${ }^{19}$ However, there are general weaknesses of the Corruption Eradication Act which affects the criminal liability of corporations, among others: the non-regulation of the definition of criminal consensus according to the Corruption Eradication Act, and the conditions for repetition of corruption (residive) according to the Law Corruption Eradication Act. So by looking at the weaknesses mentioned above, the suggestion that can be given is the Corruption Eradication Act needs to be amended.

The government must adopt a policy in the Strategic Environmental Assessment that is contained in Law Number 32 of 2009 concerning Environmental Protection and Management as a guardian of environmental sustainability in enhancing development of maintenance. Law

17 Hariman Satria. Ibid. p. 161.

18 Zul Akrial and Heni Susanti. 2017, “Analisis Terhadap Korporasi Sebagai Subyek Di dalamUndang-Undang No. 32 Tahun 2009 Tentang Perlindungan dan Pengelolaan Lingkungan Hidup”, UIR Law Review, 1(2): 137-148, p. 140.

19 P. JokoSubagyo. (2005). Hukum Lingkungan, Jakarta: RinekaCipta, p. 81. 
Number 32 of 2009 concerning Environmental Protection and Management also still leaves a lot of homework in its operation. Law Number 32 Year 2009 concerning Environmental Protection and Management that has not been able to run properly because there are no implementing regulations, which are restrained by sectoral regulations and human resources for implementation in the field is still lacking.

\section{CONCLUSION}

Based on the presentation of the previous discussion, the following conclusions are obtained; corporate responsibility is in the form of accountability for environmental criminal acts. The types of sanctions imposed on corporations for environmental crimes are in the form of criminal fines, additional crimes, and disciplinary actions. There are criminal sanctions applied to criminal subjects in the form of people who cannot be applied to corporations, such as prisons or confinement; and

The legal consequences of the application of Supreme Court Regulation Number 13 of 2016 on environmental corporate criminal offenses is related to the imposition of criminal sanctions on corporations who commit environmental crimes. Article 25 Supreme Court Regulation Number 13 of 2016 with the principal criminal is a criminal fine and then the criminal added according to the law governing environmental criminal acts is the Law Number 32 of 2009 concerning Environmental Protection and Management.

\section{Bibliography}

Abdul Roup, Muridah Isnawati and Sudarto. (2017). "Pertanggungjawaban Pidana Korporasi Lingkungan Hidup Pasca Peraturan Mahkamah Agung No. 13 Tahun 2016", Justitia Jurnal Hukum, 1(2): 294-322, < DOI: http://dx.doi.org/10.30651/justitia.v1i2.1163>.

Amiad Kushner. (2003). “Applying The Responsible Corporate Officer Doctrine Outside The Public Welfare Context”, Journal of Criminal Law \& Criminology, 93(2): 681-712.

HarimanSatria. (2017). "Penerapan Pidana Tambahan Dalam Pertanggungjawaban Pidana Korporasi Pada Tindak Pidana Lingkungan Hidup", Jurnal Yudisial, 10(2): 155-171, < DOI: http://dx.doi.org/10.29123/jy.v10i2.18>.

Hari Sutra Disemadi and KholisRoisah. (2019). "Urgency of the Contempt of Court Criminalization Policy to Overcome Harassment Against the Status and Dignity of Courts" Brawijaya Law Journal, 6(2): 224-233, < DOI: http://dx.doi.org/>.

Idi Amin. (2018). "Pertanggungjawaban Korporasi Dalam Tindak Pidana Lingkungan Hidup", Jurnal Ius Kajian Hukum dan Keadilan, 6(2): 259-263, < DOI: http://dx.doi. org/10.29303/ius.v6i2.558>.

Hari Sutra Disemadi and Nyoman Serikat Putra Jaya. (2019). "Perkembangan Pengaturan Korporasi Sebagai Subjek Hukum Pidana Di Indonesia”, Jurnal Hukum Media Bhakti, 3(2): 118-127, < DOI: https://doi.org/10.32501/jhmb.v3i2.80>.

Kristian. (2014), "Urgensi Pertanggungjawaban Pidana Korporasi", Hukum dan Pembangunan”, Jurnal Hukum Dan Pembangunan, 44(4): 575-621, < DOI: http:// dx.doi.org/10.21143/jhp.vol44.no4.36>.

Muh Abdul Qudus and Pujiyono. (2019). "Pertanggungjawaban Korporasi Terhadap Tindak Pidana Human Trafficking Di Indonesia", Jurnal Komunikasi Hukum (JKH), 5(2): 26-39, < DOI: http://dx.doi.org/10.23887/jkh.v5i2.18237>. 
Muladi and Dwidja Priyanto. (2012). Pertanggungjawaban Pidana Koorporasi. Semarang: Badan Penerbit Undip.

Oksimana Darmawan. (2018). "Pertanggungjawaban Pidana Korporasi Dalam Illegal Fishing Di Indonesia" Jurnal Yudisial, 11(2): 171-192, <DOI: http://dx.doi.org/10.29123/ jy.v11i2.292>.

P. Joko Subagyo. (2005). Hukum Lingkungan, Jakarta: Rineka Cipta.

Rusdianto Pratama. (2015). "Tindak Pidana Pencemaran Lingkungan Serta Pertanggungjawabannya Ditinjau Dari Hukum Pidana Di Indonesia”, Lex Crimen, 4(2): 105-116.

Remy Sjahdeini, Sutan. Pertanggungjawaban Pidana Korporasi (Jakarta: Gfitipers).

Yudi Krismen. (2014). "Pertanggungjawaban Pidana Korporasi dalam Kejahatan Ekonomi", Jurna IIlmu Hukum Riau, 5(1): 133-160, <DOI: http://dx.doi.org/10.30652/jih. v4i1.2089>.

Zul Akrial and Heni Susanti. 2017, “Analisis Terhadap Korporasi Sebagai Subyek Didalam Undang-Undang No. 32 Tahun 2009 Tentang Perlindungan dan Pengelolaan Lingkungan Hidup", UIR Law Review, 1(2): 137-148.

\section{Regulations:}

Supreme Court Regulation Number 13 of 2016

Law Number 32 of 2009 concerning Environmental Protection and Management

Law Number 23 of 1997 concerning Environmental Management

Law Number 20 of 2001 concerning Corruption Eradication Act

Law Number 8 of 1981 concerning Criminal Procedure Law 